\title{
SEASONAL NUTRIENT CYCLING IN INTEGRATED RICE-SHRIMP PONDS
}

2 Luu Duc Dien ${ }^{\mathrm{a}, \mathrm{b}, 1}$, Nguyen Van Sang ${ }^{\mathrm{b}}$, Stephen John Faggotter ${ }^{\mathrm{a}}$, Chengrong Chen ${ }^{\mathrm{a}}$,

3 Jianyin Huang ${ }^{\mathrm{c}}$, Peter R. Teasdale ${ }^{\mathrm{c}}$, Jesmond Sammut ${ }^{\mathrm{d}}$, Michele Astrid Burford ${ }^{\mathrm{a}}$

4

$5 \quad{ }^{a}$ Australian Rivers Institute and School of Environment \& Science, Griffith University, 170 Kessels Road,

6 Nathan, Queensland 4111, Australia

7 b Research Institute for Aquaculture No.2, 116 Nguyen Dinh Chieu Street, District 1, Ho Chi Minh City,

8 Vietnam

$9 \quad{ }^{\mathrm{c}}$ Natural and Built Environments Research Centre, School of Natural and Built Environments, University of 10 South Australia, SA 5095, Australia

11 Centre for Ecosystem Science, The School of Biological, Earth \& Environmental Sciences, The University 12 of New South Wales, Sydney 2052, Australia

\section{Abstract}

Integrated rice-shrimp ponds (IRSPs) have periods of low oxygen and high nutrient loads which may have a critical effect on both shrimp survival and water quality in adjacent waterways. To understand drivers of poor water quality, this study examined sediment nutrient pathways at two IRSPs. The study showed that the IRSPs had low denitrification efficiency. However, denitrification rates were significantly positively correlated with chlorophyll $a$ concentrations, suggesting carbon availability was a key driver of denitrification. Dissolved nutrient concentrations in the water column were relatively high despite low sediment nutrient effluxes. Given the low sediment nutrient effluxes, and low nitrogen $(\mathrm{N})$ removal by denitrification, the high nutrient loads were likely derived from incoming water. Therefore, the IRSPs were net nutrient removal mechanisms, rather than contributing to eutrophication in adjacent waterways. There also appears to be scope to enhance denitrification for increased $\mathrm{N}$ removal, via carbon addition, and hence improve water quality.

Key words: carbon; chlorophyll $a$; denitrification; nutrient fluxes; sediment.

\footnotetext{
${ }^{1}$ Corresponding author. Griffith University, 170 Kessels Road, Nathan, Queensland 4111, Australia. Tel.: +61-73735-7711; E-mail address: ducdien.luu@griffithuni.edu.au
} 
Highlights:

- IRSPs had highly variable denitrification rates with low denitrification efficiency;

- Carbon availability was a key driver of denitrification;

- High nutrient concentrations in the ponds despite low sediment nutrient fluxes;

- IRSPs are net nutrient removal mechanisms, rather than contributing to eutrophication.

\section{Introduction}

Shrimp farmers in the Mekong Delta, Vietnam, have traditionally used extensive shrimpfarming methods. Over the past few decades, however, shrimp farming has rapidly expanded, and farming systems have been diversified, and now include mangrove-shrimp and rice-shrimp systems, improved-extensive culture, semi-intensive culture and intensive culture. In the late 1980s, the price of rice declined and the original rice varieties could not grow in the coastal areas due to saline water intrusion (Khiem and Khai, 2008; Nhan et al., 2012). Farmers were therefore facing poverty, with limited opportunities for income from other sources (Khiem and Khai, 2008). To overcome this circumstance, farmers in Bac Lieu province were the first pioneers to convert rice fields to shrimp aquaculture in the dry season (Can, 2011; Preston et al., 2003). Whilst some rice growing areas have been converted to intensive shrimp monoculture, integrated rice and shrimp farming has developed where wet season salinity is low enough to continue rice cultivation using integrated rice-shrimp ponds (IRSPs). In the wet season, farmers rely on the heavy monsoon rains to reduce residual salinity in the top soil layer on the central rice platform before planting rice (Be et al., 1999). This practice makes use of the seasonal conditions (freshwater availability versus saltwater), thus rice is only grown in the wet season, while shrimp is grown in the dry season, or all year depending on the farm, when water salinity is too high to continue with rice production. This practice has increased from around 40,000 ha in 2000 (Preston et al., 2003) to 160,000 ha in 2016 and has been speculated a rise to 250,000 ha by 2030 (Tuan et al., 2016).

IRSPs contribute not only to increased income for farmers, but may also be more environmentally sustainable compared to intensive shrimp farming. Alternating rice 
farming with shrimp aquaculture could potentially reduce nutrients, i.e. N, phosphorus (P) and carbon (C), being discharged, and compared with intensive shrimp farming. It is suggested that the waste nutrients may bind to the bottom sediments, and then become utilized by the rice plants in the next cultivation cycle (Alam et al., 2010; Alongi et al., 2000; Wahab, 2003). However, little knowledge is available on biogeochemical cycles in IRSPs and how these processes are affected by the seasonal cycles. Previous studies have highlighted issues with shrimp production in IRSPs due to poor water quality, including low oxygen concentrations (Dien et al., 2018; 2019; Leigh et al., 2017). Therefore, it is necessary to understand how biogeochemical mechanisms drive water quality.

Nitrogen is a key limiting nutrient for primary production in marine systems as $\mathrm{N}$ takes more forms in soil than any other essential nutrient, and $\mathrm{N}$ transformations are usually the result of microbially-mediated soil oxidation-reduction reactions (Dong et al., 2009; Gardner and McCarthy, 2009; Jantti et al., 2011). Processes that control N availability, such as denitrification and dissimilatory nitrate reduction to ammonium (DNRA), have potentially broad ecological impacts (Dong et al., 2006; Song et al., 2013; Statham, 2012). These processes, especially denitrification, work very effectively in sewage treatment plants, and remove $\mathrm{N}$ in marine and freshwater systems (Burgin and Hamilton, 2007; Rivera-Monroy et al., 1995; Tiedje, 1988; Velinsky et al., 2017). Nevertheless, the effectiveness of denitrification in IRSPs has not been investigated. In these systems, retaining $\mathrm{N}$ in the system may enhance the productivity of rice crop, however conversely denitrification removal of excess $\mathrm{N}$ to reduce the risk of water pollution and improve water quality, and hence shrimp health (Castine et al., 2012; Gardner and McCarthy, 2009). Much of our understanding of biogeochemistry in IRSPs has focused on water column processes (Dien et al., 2018; Leigh et al., 2017). However, shrimp live at the sedimentwater interface (SWI) where chemical and biological processes in and on the sediments, and the interaction with water quality can impact shrimp health (Avnimelech and Ritvo, 2003; Paez-Osuna et al., 1997; Wiyoto et al., 2017). Therefore, fluxes in and out of the sediment play a key role in controlling the chemical composition of the IRSPs.

In this study, we compared sediment nutrient processes and their effect on water quality in both the dry and wet seasons in IRSPs. The potential factors controlling sediment nutrient fluxes, including denitrification and DNRA, were also examined, with a view to 
understanding the potential to enhance sediment biogeochemical processes and hence improve water quality.

\section{Materials and methods}

\subsection{Study area}

This study focused on two IRSPs in Thoi Binh District, Ca Mau province, Vietnam (Fig. 1). Rice-shrimp ponds have a platform (80\% of area) for growing rice, and a surrounding ditch (20\% of area) for water management and shrimp farming. IRSPs ranged in size from 1.5 to 2.0 ha, with water depth in the ditch typically $1.0-1.4 \mathrm{~m}$, and for the platform $0.1-$ $0.4 \mathrm{~m}$. The ponds was previously a mangrove forest. Since 1980s, farmers in the area started replacing mangrove forest with rice as a food supply. From 2007, with the promotion from local government and the high market price from shrimp, farmers turned into IRSPs.

There are two main seasons in the region: the dry season from December to April, and the wet (rainy) season from May/June to October/November (Leigh et al, 2017). The hottest period is typically between April and May, while the wettest period is from September to October/November. During the dry season, water salinities range between brackish and seawater conditions, while in the rainy season, salinity typically drops gradually from around seawater to brackish, and may become fresh (ADB, 2013; Tho et al., 2006; Tho et al., 2013). The air temperature ranges from 24 to $34^{\circ} \mathrm{C}$, and the mean monthly rainfall ranges from $0 \mathrm{~mm}$ in the dry season to $250 \mathrm{~mm}$ in the wet season, with an annual rainfall of around $2300 \mathrm{~mm}$ (ADB, 2013).

\subsection{Pond management and harvesting}

The first step to prepare the IRSPs for this field trial involved cleaning and reinforcing the pond bank, discharging the water in the ditch through a sluice gate, and transferring accumulated sludge from the ditch to the rice-growing platform. Lime was then added to the pond (using calcium oxide, a dose of $1 \mathrm{t} \mathrm{ha}^{-1}$ ditch$^{-1}$ and $500 \mathrm{~kg} \mathrm{ha}^{-1}$ platform ${ }^{-1}$ ), then the platform was dried for 5-7 d. Approximately 15-20 d later, water was added from the canal, via a filter bag to remove unwanted organisms, provided the salinity of the supply 
121 channel was suitable $(>10)$. The depth of water in the ditch was about $1.2 \mathrm{~m}$. Unwanted

122 fish were killed using Rotenone, and water was disinfected using iodine added at $0.5 \mathrm{mg} \mathrm{L}^{-}$

$123{ }^{1}$ (Boyd, 1995). A few days later, fertilizer was added (using di-ammonium phosphate or

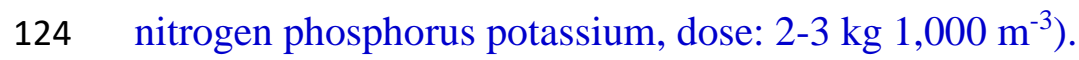

125 IRSPs were stocked with $P$. monodon with a mean density of 1.5 to 2.0 post larvae $\mathrm{m}^{-2}$.

126 Stocking occurred every 3-4 months during the two-year period over both the wet and dry

127 season. No formulated feed was added. During the crop, depend on water colour, water

128 exchange of around one-third pond volume was conducted, and probiotics were sometimes 129 added.

130 Rice was planted at a density of $4.0 \mathrm{~kg} 1000 \mathrm{~m}^{-2}$. Rice was grown through to the end of the dry season and harvested in December with short-term varieties (OM429, OM18) or January with long-term variety (Lun Kien Giang).

Trap nets with a large mesh size (12 mm) were used for partial harvests frequently throughout the year to ensure that only shrimp greater than 20 g were caught and removed from the ponds. At the end of the year, the ponds were drained, and remaining shrimp were harvested using trap or seine nets.

\subsection{Nutrient and physicochemical data}

139 Water temperature and salinity in the ditch of the two IRSPs were logged at two-hour intervals throughout each year using calibrated loggers (Thermocron ibuttons, Odyssey conductivity probes). During each experiment, physico-chemical parameters, i.e. temperature, salinity, $\mathrm{pH}$ and $\mathrm{DO}$, were measured daily in the ditch (around $0.5 \mathrm{~m}$ from the surface) throughout 2016 and 2017, using a calibrated Hydrolab Quanta multi-parameter probe. Light attenuation was calculated after measuring light intensity through the water column using a Licor LI-250A with a 4 pi-sensor.

146 From the start of 2016 to the end of 2017, water samples for nutrients and other parameters were collected twice each year during the experiments (in both dry and wet seasons). For nutrient analyses, water samples from the surface were taken at five different locations in the ditch using a $1 \mathrm{~L}$ bottle. Each bottle of water was poured into one bucket to make a composite sample (three replicates) from which subsamples for various analyses were 
taken. For chlorophyll $a$ analyses, known volumes of water were filtered through glass fibre filters (Whatman GF/F with nominal pore size $0.7 \mu \mathrm{m}, 2.5 \mathrm{~cm}$ diameter). Filters were stored on ice and later frozen at $-20^{\circ} \mathrm{C}$ until analyzed. A similar sampling method was applied for ash free dry weight (AFDW) and total suspended solid (TSS) parameters.

Two replicate water samples were taken and frozen at $-20^{\circ} \mathrm{C}$ for measurements of total organic carbon (TOC), total nitrogen (TN), total phosphorus (TP) and sulfide. For ammonium nitrogen $\left(\mathrm{NH}_{4}{ }^{+}-\mathrm{N}\right)$, nitrite nitrogen $\left(\mathrm{NO}_{2}{ }^{-}-\mathrm{N}\right)$, nitrate nitrogen $\left(\mathrm{NO}_{3}{ }^{-}-\mathrm{N}\right)$, soluble reactive phosphate ( $\left.\mathrm{PO}_{4}{ }^{3-}-\mathrm{P}\right)$, total dissolved nitrogen (TDN) and total dissolved phosphorus (TDP) analyses, a subsample was taken and filtered through a $0.45 \mu \mathrm{m}$ membrane filter (Sartorius, $2.5 \mathrm{~cm}$ diameter), then the filtrate was kept frozen until analyzed.

$\mathrm{NH}_{4}-\mathrm{N}$ was analyzed using the phenate method; $\mathrm{NO}_{2}-\mathrm{N}, \mathrm{NO}_{3}-\mathrm{N}$ using cadmium reduction and sulphanilamide method; $\mathrm{PO}_{4}-\mathrm{P}$ using the ascorbic acid method, and TP, TDP, TN and TDN using the persulfate method followed by colourimetric analyses (APHA, 2005). Concentrations of chlorophyll $a$ were determined by acetone extraction of the glass fibre filters, and spectrophotometric measurements following APHA methods (2005). TOC was determined following APHA methods (2005) using the chromic acid rapid titration method. Sulfide concentrations were measured through the methylene blue method using a UV-VIS Thermo Spectronic Helios Alpha spectrophotometer (APHA, 2005). For TSS samples, filters were defrosted then dried in an oven at $60^{\circ} \mathrm{C}$ for $24 \mathrm{~h}$ before being weighed while AFDW samples were combusted at $550^{\circ} \mathrm{C}$ for $4 \mathrm{~h}$, then weighed (APHA, 2005).

Sediment samples were taken twice in 2016 (once in the dry season and once in the wet season) by collecting five cores (up to $15 \mathrm{~cm}$ depth) in the ditch, and five cores in the platform from each pond. All sediment samples were oven-dried at $60^{\circ} \mathrm{C}$ for $24 \mathrm{~h}$, pulverized to pass through a $0.25 \mathrm{~mm}$ mesh screen, and analyzed for TN, TP and TC (APHA, 2005). The method for sediment chlorophyll $a$ concentrations was the same as for water column chlorophyll $a$ concentrations, but cores of known diameter, and 2-cm deep were used for the acetone extractions.

\subsection{Denitrification}


181 From 2016 to 2017, denitrification incubations were conducted in the dry (April 2016,

182 April 2017) and the wet seasons (October 2016, October 2017). Intact cores from the ditch and platform were collected using a pole corer; samples were collected by wading onto the platform or from a boat (ditch). For each sediment incubation, 16 cores were taken from the ditch (or the platform) of one pond, which were then put in a plastic container (60L plastic crate). Sediment reached a predetermined height in the Perspex core tube that was capped at the base with a rubber bung. Overlying water was removed to avoid sediment resuspension during sampling, and cores were transported to an incubation site adjacent to the ponds.

Prior to running the incubations, all cores were equilibrated for about $8 \mathrm{~h}$ with around $450 \mathrm{~mL}$ of filtered rice-shrimp pond water to ensure water saturation of the pore space. A Teflon-coated stirrer bar was then suspended around $5 \mathrm{~cm}$ above the sediment. This was driven by an external rotating magnet rotating at 60-70 rpm which was located in the middle of the nally bin. The nally bin was filled with water such that the cores were immersed (if necessary to buffer temperature). In this step, cores were collected in the afternoon, and then equilibrated overnight before commencing the experiment early the following day.

After equilibration, the incubations followed the method of Burford et al. (2009). The water level was reduced to below core tube height and experiments commence with the addition of stock ${ }^{15} \mathrm{~N}$-potassium nitrate (Cambridge, $99 \%{ }^{15} \mathrm{~N}$ atom) to a concentration of $60 \mu \mathrm{mol} \mathrm{L}{ }^{-1} \mathrm{~N}$. This concentration was assumed to be a saturating concentration based on studies by Cook et al. (2004). The water in each core was stirred for $20 \mathrm{~min}$ and subsamples taken for the analysis of nitrate concentrations to calculate the final ${ }^{15} \mathrm{~N}$ enrichment.

205 Cores were sacrificed at 8 points [5 points $(0,1.5,3.0,4.5,6.0 \mathrm{~h})+3$ points with dark 206 cover $(1.5,3.0,6.0 \mathrm{~h})]$. At each time point, $1.0 \mathrm{~mL}$ of $50 \%$ zinc chloride was added to the water overlying the sediment before the sediment was gently slurried with the water column using a metal rod; coarser particles were allowed to settle for about a minute before a subsample was taken using a gas-tight syringe. The sample was then placed in a $12.5 \mathrm{~mL}$ Exetainer (Labco, High Wycombe, UK) to which $250 \mu \mathrm{L}$ of $50 \% \mathrm{w} / \mathrm{v}$ zinc

211 chloride is added and stored at $4^{\circ} \mathrm{C}$ until returned to the laboratory. 
212 The isotope samples were analyzed by mass spectroscopy. A headspace of helium was

213 introduced into the Exetainer within two weeks and the samples were then analyzed within

214 two months. Headspace analysis for ${ }^{28} \mathrm{~N}_{2}-{ }^{-29} \mathrm{~N}_{2}{ }^{-}$and ${ }^{30} \mathrm{~N}_{2}^{-}$nitrogen gas was carried out by

215 removing a 50 $\mu \mathrm{L}$ sample in a gas-tight syringe and injecting into a Sercon Europa EA-

216 GSL elemental analyzer coupled to a Hydra-20-20 continuous flow isotope ratio mass

217 spectrometer. A copper reduction column heated to $640^{\circ} \mathrm{C}$ was used to remove oxygen

218 from the sample; carbon dioxide and water were removed using a liquid $\mathrm{N}$ cryotrap.

219 Denitrification rates were calculated according to the isotope pairing equations in

220 Dalsgaard et al. (2000).

221 To determine the denitrification efficiency (\% $\mathrm{N}$ was removed from the pond), firstly

222 denitrification rate across the whole pond was calculated: Denitrification rate across the

223 whole pond $=$ [(rate in ditch $\mathrm{x}$ ditch area $)+($ rate in platform $\mathrm{x}$ platform area $)] /$ total area of

224 the pond. After that, \% $\mathrm{N}$ removal by Denitrification $=\mathrm{N}$ removal by denitrification

225 (kg/year) x 100\% / Total N in the pond (kg/year).

226

227

\subsection{Dissimilatory nitrate reduction to ammonium (DNRA)}

228 To compare the N pathway, we conducted the experiment on DNRA twice in 2017 (once

229 in the dry season and once in the wet season) at the same time as denitrification

230 experiment.

231 The sampling protocol and experiment were similar to the methods used to evaluate

232 denitrification. The pole corer was used to collect 16 cores in total in both ditches and

233 platforms of two IRSPs. $1 \mathrm{~mL}^{15} \mathrm{~N}-\mathrm{NO}_{3}$ was added to each core. These incubations

234 followed the method of Dong et al. (2009). At the end of the incubation, the sediment core

235 and water were mixed to form a slurry, and then samples $(10 \mathrm{~mL})$ of the slurried sediment

236 cores were taken for the subsequent recovery of ${ }^{15} \mathrm{NH}_{4}{ }^{+}$to determine rates of DNRA.

237 Samples were run through the Sercon Europa EA-GSL elemental analyzer coupled to a

238 Hydra-20-20 continuous flow isotope ratio mass spectrometer. Reference standards and

239 blanks were run prior to analysis and after every 10th sample.

240 DNRA rates were determined following the method of Dong et al. (2009). The rate of

241 DNRA was calculated as follows: rate of DNRA $\left(\mu m o l ~ \mathrm{~N} \mathrm{~m}^{-2} \mathrm{~h}^{-1}\right)={ }^{15} \mathrm{~N}$ excess $\mathrm{x}$ amount 
of $\mathrm{NH}_{4}{ }^{+}(\mu \mathrm{mol}$ of $\mathrm{N})$ in $1 \mathrm{~mL}$ of slurry $\mathrm{x} \mathrm{V}(\mathrm{mL}) /{ }^{15} \mathrm{~N}$ enrichment/incubation time (h) $\mathrm{x}$,

243 where:

$244{ }^{15} \mathrm{~N}$ excess $=2 \mathrm{x}\left[\left(\right.\right.$ sample ${ }^{30} \mathrm{~N} /{ }^{28} \mathrm{~N}$ ratio) - (reference ${ }^{30} \mathrm{~N} /{ }^{28} \mathrm{~N}$ ratio $\left.)\right]+\left[\left(\right.\right.$ sample ${ }^{29} \mathrm{~N} /{ }^{28} \mathrm{~N}$ ratio) - (reference ${ }^{29} \mathrm{~N} /{ }^{28} \mathrm{~N}$ ratio)];

Amount of $\mathrm{NH}_{4}{ }^{+}$in $1 \mathrm{~mL}$ of slurry $=\mathrm{NH}_{4}{ }^{+}$concentration $(\mu \mathrm{mol})$ x volume of distillate (L)/10 mL of slurry;

V was the total slurry volume per square meter of sediment $(\mathrm{V}=$ height of core $(\mathrm{cm}) \times 100$

${ }^{15} \mathrm{~N}$ enrichment $={ }^{15} \mathrm{NO}_{3}{ }^{-} /\left({ }^{15} \mathrm{NO}_{3}{ }^{-}+{ }^{14} \mathrm{NO}_{3}{ }^{-}\right)$ratio;

$\mathrm{R}$ was the ${ }^{14} \mathrm{NO}_{3}{ }^{-} /\left({ }^{15} \mathrm{NO}_{3}{ }^{-}+{ }^{14} \mathrm{NO}_{3}{ }^{-}\right)$ratio in the water column.

\subsection{Nutrient fluxes}

Nutrient fluxes experiments were conducted twice each year (both in the dry season and wet season) during the two-year period from 2016 to 2017, at the same time as the denitrification experiments.

Intact cores from the ditch and platform were collected by wading onto the platform or from a boat (ditch) with the pole corer. For each sediment incubation, 12 cores were taken from two ponds [(three replicates in the ditch + three replicates in the platform) $\times$ two ponds]. Overlying water was removed to avoid sediment resuspension during sampling and cores were transported to an incubation site adjacent to the ponds. Prior to running the incubations, all cores were equilibrated for about $8 \mathrm{~h}$ with around $450 \mathrm{~mL}$ of filtered riceshrimp pond water to ensure water saturation of the pore space.

Prior to commencing measurements, cores were completely filled with rice-shrimp pond water above the cores to remove any gas space, and sealed without disturbance of the sediment surface. The incubations were conducted using the method of Kaiser et al. (2015). The cores were incubated in a container (a nally bin) with constantly flowing pond water to maintain the same temperature as the pond. The water velocity within cores was controlled by a $12-\mathrm{V}$ pump at $2-3 \mathrm{~cm} \mathrm{sec}^{-1}$, the lowest velocity that resulted in a linear decline in DO concentration over time (Reay et al., 1995). This maintained aerobic 
conditions at the sediment-water interface but did not suspend fine clay particles (Zhong et al., 2015). The light levels in the cores were also controlled as the same condition as ponds. Water samples for nutrient analyses were drawn every $3 \mathrm{~h}$ for $24 \mathrm{~h}$ through a sampling port in the cover cap. Using this port, the extracted volume was replaced with pond water to maintain the incubated volume and to ensure constant concentrations in the replacement water. To prevent stratification of the water column and the generation of concentration gradients, incubated water was continuously circulated using the mentioned above the 278 peristaltic pump.

The methods for nutrient analyses were the same as for water column nutrients. Fluxes of nutrients $\left(\mathrm{NH}_{4}{ }^{+}, \mathrm{NO}_{2}^{-}, \mathrm{NO}_{3}^{-}, \mathrm{PO}_{4}{ }^{3-}\right)$ and $\mathrm{S}^{2-}$ in individual incubation cores were calculated by linear regression of concentration (corrected for dilution) over time. Negative values represent influxes, positive ones represent effluxes. We also compared fluxes on the ditch and platform separately, but they were not statistically different, hence we combined results.

\subsection{IRSPs sediment pore-water profiles}

287 To confirm the results of nutrient fluxes, we deployed the diffusive equilibrium in thin films (DET) method in the sediment of both IRSPS twice in 2017 (once in the dry season and once in the wet season) (Davison et al., 1994; Krom et al., 1994; Zhang and Davison, 1999). DET probes contained $1.25 \mathrm{~mm}$ thick agarose gel layers which were overlaid with a $0.1 \mathrm{~mm}$ polyethersulfone filter membrane. The probes were inserted into the sediment and the hydrogel layer equilibrated with the adjacent sediment pore-water over several deployment times (Davison et al., 1994; Krom et al., 1994; Zhang and Davison, 1999). This technique enabled us to measure solute concentration profiles and determined the solute fluxes. All experiments were conducted in situ in both the ditch and platform of two IRSPs, and used a single gel for analyzing each parameter $\left(\mathrm{NH}_{4}{ }^{+}\right.$, or $\mathrm{NO}_{2}{ }^{-}$, or $\mathrm{NO}_{3}{ }^{-}$, or $\mathrm{PO}_{4}{ }^{3-}$ or $\left.\mathrm{S}^{2-}\right)$.

In the pre-treatment stage, the gel probes were put into a similar salinity solution of IRSPs and deoxygenated overnight by using ultra high purity grade compressed nitrogen gas (99.999\%) before deployment. In the dry season, we prepared a $0.7 \mathrm{~mol} \mathrm{~L}^{-1} \mathrm{NaCl}$ solution 
301

302

303

304

305

306

307

308

309

310

311

312

313

314

315

316

317

318

319

320

321

322

324

325

326

327

328

329

while a $0.01 \mathrm{~mol} \mathrm{~L}^{-1} \mathrm{NaCl}$ solution was used in the wet season. After that, the probes in solutions were pumped with $\mathrm{N}_{2}$ gas at low speed overnight before deployment. Next, extra water was wiped from the gel probes. Probes were then pushed into sediment vertically, and 3-4 h was allowed for probes to reach equilibrium.

After this time, gel probes were collected and tissues were used to remove the sediment on gel probes from the top to bottom to minimise contamination. The open window was sliced and placed on the cutting sheet, then the gel was sliced into $1.0 \mathrm{~cm}$ wide sections. The sliced gel was put into the $10 \mathrm{~mL}$ tube which was then stored in a freezer before elution and analysis. Ethanol was used to wipe the cutting sheet before slicing other gels. It should be noted that the gels must be sliced immediately after being removed from the sediment to avoid internal diffusion, and then kept frozen. On removal, $10 \mathrm{~mL}$ of deionised water was added to elute the nutrient from the gels. For those freezing gels, the elution time was about $6 \mathrm{~h}$. The eluents were then transferred into another tube, and the samples were used for analysis. In the calculation, final nutrient concentration in the gel = dilution factor $\mathrm{x}$ the nutrient concentration in the eluent. Dilution factor $=($ Eluent volume + gel volume $) / g e l$ volume $=(10+0.22) / 0.22=46.5$, where: the eluent volume was $10 \mathrm{~mL}$ (the $\mathrm{mL}$ of deionised water was put into the gel); the gel volume was about $0.22 \mathrm{~mL}$ (when the gel was sliced into $1 \mathrm{~cm}$ wide). Therefore, final nutrient concentration in the gel $=46.5 \mathrm{x}$ the nutrient concentration in the eluent.

The potential nutrient diffusion flux (F) across SWI, measured by DET, was calculated with a one-dimensional pore water diffusion model. The diffusion flux could be estimated by Fick's first law (Mortimer et al., 1998):

$$
F=\varphi D_{S}\left(\frac{\partial c}{\partial x}\right)
$$

where $F$ was across SWI diffusion flux $\left(\mathrm{mmol} \mathrm{m}^{-2} \mathrm{~d}^{-1}\right), \partial \mathrm{c} / \partial \mathrm{x}$ was the concentration gradient at SWI (mmol L $\left.\mathrm{cm}^{-1}\right), D s=\varphi 2 D_{0}(\varphi>0.7)$ or $D s=\varphi D_{0}(\varphi<0.7), D_{0}$ was the ideal diffusion coefficient for an infinitely dilute solution (for $\mathrm{NH}_{4}{ }^{+}-\mathrm{N}, D_{0}=19.8 \times 10^{-6} \mathrm{~cm}^{2}$ $\mathrm{s}^{-1}$ in both the dry and the wet season; for $\mathrm{NO}_{2}^{-}-\mathrm{N}, D_{0}=19.1 \times 10^{-6}$ and $15.3 \mathrm{~cm}^{2} \mathrm{~s}^{-1}$ in the dry and the wet season, respectively; for $\mathrm{NO}_{3}{ }^{-}-\mathrm{N}, D_{0}=19.0 \times 10^{-6}$ and $16.1 \mathrm{~cm}^{2} \mathrm{~s}^{-1}$ in the dry and the wet season, respectively; for $\mathrm{PO}_{4}{ }^{3-}-\mathrm{P}, \mathrm{D}_{0}=8.4 \times 10^{-6}$ and $7.15 \mathrm{~cm}^{2} \mathrm{~s}^{-1}$ in the dry 
and the wet season, respectively; for $\mathrm{S}^{2-}, D_{0}=6.95 \times 10^{-6} \mathrm{~cm}^{2} \mathrm{~s}^{-1}$ in both the dry and the wet season), and $\varphi$ was the porosity of sediments (Kuwae et al., 2003; Urban et al., 1997).

\subsection{Data analysis}

Statistical analysis of the data was performed using a statistical package (R Studio and SPSS 20.0 for Windows). The denitrification rate and DNRA rates were compared between seasons (dry and wet) and position (ditch and platform) using analysis of variance (ANOVA), followed by Duncan's multiple range tests for post hoc comparisons to determine the significant differences at the $5 \%$ significance level. The normal distribution of the data and homogeneity of variances among the treatments was tested prior to the ANOVA. Correlations between denitrification rates and parameters in the water column (e.g. salinity, chlorophyll $a$, DO), and sediment (chlorophyll $a$, TOC, TN, TP), were examined using linear regression models. The strength of the correlations was established using Pearson's correlation coefficient $(r)$ and the $p$-value.

\section{Results}

\subsection{Background water and sediment information}

Water temperatures typically ranged from 29 to $35^{\circ} \mathrm{C}$ in the dry season, and 26 to $32^{\circ} \mathrm{C}$ in the wet season (Fig. 2). However, during the first experiment, i.e. April 2016, the water temperature was close to $40^{\circ} \mathrm{C}$ while the salinity was more than 35 ppt. The mean salinity in the dry season over the two-year period was $29.3( \pm 14.9)$ ppt, whereas it was only 2.9 $( \pm 0.8)$ ppt in the wet season (Table 1, Fig. 2).

The mean ammonium concentration in the dry season was $0.148 \mathrm{mg} \mathrm{L}^{-1}$, this was approximately $50 \%$ of the corresponding value in the wet season $\left(0.287 \mathrm{mg} \mathrm{L}^{-1}\right)$ (Table 1$)$. The concentration of nitrite in the wet season was approximately four times higher than that in the dry season (0.039 and $0.011 \mathrm{mg} \mathrm{L}^{-1}$ respectively). In contrast, the mean concentration of nitrate in the dry season was $0.232 \mathrm{mg} \mathrm{L}^{-1}$, more than three times higher than that in the wet season $\left(0.067 \mathrm{mg} \mathrm{L}^{-1}\right)$. The mean concentration of phosphate was approximately $0.115 \mathrm{mg} \mathrm{L}^{-1}$ in both the dry and the wet season. However, despite the differences in values, the high variability meant that there were no major differences $(p>$ 
0.05) in concentrations in nutrient parameters in the wet and dry seasons. The euphotic depth ranged from 1.2 to $1.6 \mathrm{~m}$ in the dry season, and between 0.6 and $0.8 \mathrm{~m}$ in the wet season (Table 1).

The mean concentration of chlorophyll $a$ in the water column in the dry season during the experiments was $12.3 \mu \mathrm{g} \mathrm{L}^{-1}$, which was only $25 \%$ of the wet season value $\left(55.8 \mu \mathrm{g} \mathrm{L}^{-1}\right)$ (Table 1). The opposite was true for chlorophyll $a$ concentrations in the sediment which were $2.95 \pm 1.54 \mathrm{mg} \mathrm{m}^{-2}$ in the dry season, substantially higher than that in the wet season $\left(0.16 \pm 0.09 \mathrm{mg} \mathrm{m}^{-2}\right)$ (Table 2).

Sediment nutrients and organic carbon concentrations in the sediment were also highly variable with no significant differences $(p>0.05)$ between sites within ponds, or between seasons (Table 2).

\subsection{Denitrification and DNRA rates}

Denitrification rates in the dry season were statistically higher than for the wet season $(p<$ 0.05 , Fig. 3). Specifically, $81.3 \pm 37.9 \mu \mathrm{mol} \mathrm{N} \mathrm{m}^{-2} \mathrm{~h}^{-1}$ was removed via denitrification in the dry season, compared with $52.4 \pm 27.2 \mu \mathrm{mol} \mathrm{N} \mathrm{m} \mathrm{N}^{-2} \mathrm{~h}^{-1}$ in the wet season (Fig. 3). The denitrification rate in the ditch $\left(65.1 \pm 31.7 \mu \mathrm{mol} \mathrm{N} \mathrm{m} \mathrm{N}^{-2} \mathrm{~h}^{-1}\right)$ was statistically higher $(p<$ 0.05) than the platform $\left(49.2 \pm 28.6 \mu \mathrm{mol} \mathrm{N} \mathrm{m}^{-2} \mathrm{~h}^{-1}\right)$ (Fig. 3). Denitrification rates were lower during the day (i.e. light conditions) $\left(50.2 \pm 27.6 \mu \mathrm{mol} \mathrm{N} \mathrm{m} \mathrm{N}^{-2} \mathrm{~h}^{-1}\right)$ compared to the night (i.e. dark conditions) $\left(64.7 \pm 38.2 \mu \mathrm{mol} \mathrm{N} \mathrm{m} \mathrm{N}^{-2} \mathrm{~h}^{-1}, p<0.05\right)$. There was no significant difference between values for 2016 and 2017 ( $p>0.05$ ). In terms of denitrification efficiency, denitrification could remove from 1.1 to $2.3 \% \mathrm{~N}$ annually (with a mean of 1.7\%) from the IRSPs (Table 3).

There was a significant positive correlation between denitrification rates and concentrations of chlorophyll $a$ in the sediment $(p<0.05)$ (Table 4). However, no water column parameter was found to be significantly correlated with the denitrification rate $(p>$ $0.05)$.

DNRA rates differed between the dry and wet seasons $(p<0.05)$. Specifically, DNRA rate in the dry season was around $1.0 \mathrm{nmol} \mathrm{m}^{2} \mathrm{~h}^{-1}$, which was just approximately $25 \%$ of the wet season value (Fig. 4). However, there was no significant difference between the ditch and platform $(p>0.05)$ (Fig. 4). 


\subsection{Nutrient fluxes}

The nutrient flux rates showed no consistent patterns between years and seasons. Nearly all fluxes were negative, reflecting influx into the sediment (Table 5). The exception was net $\mathrm{NH}_{4}{ }^{+}$efflux in the dry season in 2016, $\mathrm{S}^{2-}$ in the wet 2017, and $\mathrm{PO}_{4}{ }^{3-}$ at times in 2017. The highest nutrient flux rates from the sediment were those of $\mathrm{NH}_{4}^{+}$, followed by $\mathrm{NO}_{3}{ }^{-}$. Fluxes of $\mathrm{NO}_{2}{ }^{-}, \mathrm{PO}_{4}{ }^{3-}$, and $\mathrm{S}^{2-}$ were significantly lower compared to $\mathrm{NH}_{4}{ }^{+}$.

\subsection{IRSPs sediment pore-water profiles}

The nutrient profiles determined from the DET method showed that the pore-water concentrations of $\mathrm{NH}_{4}{ }^{+}, \mathrm{NO}_{2}{ }^{-}, \mathrm{NO}_{3}{ }^{-}$and $\mathrm{S}^{2-}$ decreased rapidly at the sediment water interface (SWI, $0 \mathrm{~cm}$ sediment depth), while $\mathrm{PO}_{4}{ }^{3-}$ increased with sediment depth (Fig. 5). There were significant differences of $\mathrm{NH}_{4}{ }^{+}$and $\mathrm{PO}_{4}{ }^{3-}$ concentrations between the dry and the wet seasons. Depth-integrated concentrations of $\mathrm{NH}_{4}{ }^{+}$in the dry season ranged from around 400-1000 $\mathrm{gg} \mathrm{L}^{-1}$, compared with between 200 and $600 \mu \mathrm{g} \mathrm{L}^{-1}$ in the wet season. For $\mathrm{PO}_{4}{ }^{3-}$, the concentrations in the dry and wet seasons were 30-450 $\mu \mathrm{g} \mathrm{L}^{-1}$ and 20-250 $\mu g \mathrm{~L}^{-1}$, respectively. Other parameters $\left(\mathrm{NO}_{2}{ }^{-}, \mathrm{NO}_{3}{ }^{-}, \mathrm{S}^{2-}\right)$ did not show significant differences between seasons.

Most of the fluxes, based on the DET method, were negative, indicating an influx from SWI to the sediment in both the dry and wet seasons (Table 6). The only exceptions were $\mathrm{S}^{2-}$ in the wet season, and $\mathrm{PO}_{4}{ }^{3-}$ in both seasons. The flux results determined by the DET method were similar to the nutrient flux results using the core incubation method. The calculated flux from the water surface to SWI showed the opposite results and most of the fluxes were positive, with the exception of $\mathrm{NO}_{3}{ }^{-}$and $\mathrm{PO}_{4}{ }^{3-}$, which was negative in the wet season and in both seasons, respectively.

\section{Discussion}

Our study showed that the annual $\mathrm{N}$ removal from denitrification in the IRSPs was around $1.7 \%$, hence the $\mathrm{N}$ lost from denitrification was relatively low. However, at some sites within the ISRPs, denitrification rates were higher, thus there was scope to enhance rates. One feature of these ponds was the presence of dead mangrove roots from the former 
mangrove forest that had been cleared for farming; the mangrove roots were part of the soil matrix and not fully decomposed due to the reducing soil conditions. Kaiser et al. (2015) highlighted that low respiration rates and a decrease in oxygen concentrations were due to a lack of bioturbation (e.g., crab burrows) and mangrove roots. It was possible that areas close to these roots may provide suitable sites for denitrification. Increased oxygen diffusion along root channels or organic carbon heterogeneity, resulting from root exudates and decay, could create suitable micro-sites to enhance coupled nitrification-denitrification (Alongi et al., 2000; Kartal et al., 2007).

Denitrification rates were higher in the dry season, based on the higher rates compared to the wet season. This may be explained by higher water temperatures and $\mathrm{NO}_{3}{ }^{-}$ concentrations in the dry season (Koch et al., 1992; Kraft et al., 2014). Higher temperatures increase microbial anaerobic respiration, while higher $\mathrm{NO}_{3}{ }^{-}$concentrations provided the necessary electron acceptor for denitrification (Amatya et al., 2009). Similarly, the differences of denitrification rates between day and night in the sediment suggested competition with algae in the IRSPs for nitrate, because algae use nitrate when photosynthesizing during the day (Dong et al., 2006). Sulfide was present in the water column and also in the sediment, thus this may also account for the low denitrification rates in some sites (Jensen et al., 2007).

In our study, denitrification rates were significantly positively correlated with chlorophyll $a$ concentrations in the sediment, meaning that organic carbon derived from benthic algae may drive denitrification in the IRSPs (Alongi, 2014). Therefore, in the IRSPs, organic carbon seemed to be the factor controlling denitrification.

The denitrification rates in this study were higher than those in intensive shrimp ponds, i.e. $39.0 \pm 9.0 \mu \mathrm{mol} \mathrm{m}{ }^{-2} \mathrm{~h}^{-1}$ (Castine et al., 2012) compared to $81.3 \pm 37.9 \mu \mathrm{mol} \mathrm{m}^{-2} \mathrm{~h}^{-1}$ in the dry season and $52.4 \pm 27.2 \mu \mathrm{mol} \mathrm{m}^{-2} \mathrm{~h}^{-1}$ in the wet season in this research. Our results were 6-9 times higher than the denitrification rates in a study of shrimp mangrove sediments, the highest being only $9.4 \mu \mathrm{mol} \mathrm{m}{ }^{-2} \mathrm{~h}^{-1}$ (Rivera-Monroy et al., 1995). However, rates were much lower compared to natural systems where denitrification can remove up to $266 \mathrm{mmol}$ $\mathrm{m}^{-2} \mathrm{~d}^{-1}$, i.e. $11,083 \mu \mathrm{mol} \mathrm{m} \mathrm{m}^{-2} \mathrm{~h}^{-1}$ (Dalsgaard et al., 2003). Therefore, in comparison with natural systems, denitrification in IRSPs was less efficient, meaning that higher $\mathrm{N}$ was retained in IRSPs. This was likely because of the high nitrogen loads from the adjacent 
canal and inputs such as fertilizer, important factors governing denitrification in agricultural and aquaculture soils. Previous research on nutrient budgets in IRSPs by Dien et al. (2018) showed that water intake was the main nutrient and carbon input (92\% N, $57 \%$ P, 95\% C) while fertilizer addition only accounted for $8 \%$ N, 43\% P and 5\% C. This analysis excluded carbon from primary productivity.

457 Our study showed that nutrients migrated from surface water into SWI, and this might be caused by fine flocculated material on the sediment surface (Zhong et al., 2015). Ammonium and nitrite were likely to be mobilized at the SWI, and then diffused into the surface water and the sediment. In contrast, the phosphate had been consumed at the SWI, and phosphate from the surface water and sediment then migrated to the SWI (Figure 4). Some parameters had a peak between the SWI and the water surface, which suggested that total production was greater than all losses (including fluxes). For those troughs indicate sites where consumption was greater than production (Berg et al., 1998; Wang et al., 2008). In most of the sites in the IRSPs, the DET method also showed a negative flux from the sediment to SWI, which correlated well with nutrient flux data (Table 5).

Sediment nutrient fluxes had limited effect on water column nutrients since nutrients were mostly in-fluxing into the sediment. This combined with the low rates of nitrogen loss from denitrification, means that the high $\mathrm{NO}_{3}{ }^{-}, \mathrm{NH}_{4}{ }^{+}$and $\mathrm{PO}_{4}{ }^{3-}$ concentrations in the water column were likely from the canal supplying water to the ponds. This was consistent with a previous study on nutrient budgets in IRSPs (Dien et al., 2018). From this point of view, water discharge from IRSPs has a low environmental impact.

The high nutrient concentrations in the canal water were most probably due to anthropogenic sources in the highly exploited water system of the Mekong Delta. Farmers from all over the Mekong Delta have migrated in large numbers to this region and settled along nearly all canals and rivers (Binh et al., 2005). Tho et al. (2006) reported that canals were under particular pressure from point sources of pollution, due to boat traffic effects, and effluent from community markets, and this might have an important impact on water quality on a regional basis.

DNRA rates were low as opposed to denitrification rates in this study. Castine et al. (2012) also showed that denitrification was the dominant $\mathrm{N}_{2}$ production pathway in a tropical aquaculture settlement pond. In contrast, the dominance of DNRA over denitrification 
occurred in an environment with relatively high liable carbon, and reduced sulfur and iron

484 (Giblin et al., 2013). Dong et al. (2011) highlighted that DNRA seemed to be a dominant N reduction pathway (compared to denitrification) in tropical estuarine systems with high temperatures, low sediment organic content and low water column $\mathrm{NO}_{3}{ }^{-}$concentrations. However, this study shows that the IRSPs had relatively high sediment organic content and water column $\mathrm{NO}_{3}{ }^{-}$concentrations, hence DNRA rates were low in this integrated system (i.e IRSPs).

There were significant differences in denitrification, DNRA and nutrient fluxes between the dry and the wet season in this research. Salinity changes should be the reason for these results. The extremes of the changing salinity across seasons were likely to limit bacterial and other biogeochemical processes (Giblin et al., 2010; Koch et al., 1992). This may prevent the establishment of stable bacterial communities, and hence reduce rates of key processes, such as denitrification.

This study points to benefits of IRSP farming methods, compared with shrimp farming, in terms of improvements to water quality. Deterioration of water quality and associated effects on coastal areas adjacent to intensive shrimp farming has been shown to be a major issue globally (Díaz et al., 2012; Tho et al., 2013). Therefore, IRSP systems appear more environmentally sustainable. However, there remain challenges with these IRSPs, such as variable shrimp and rice production, due to water quality issues, e.g. low oxygen conditions (Leigh et al. 2017). The poor water quality of the adjacent canals is therefore affecting the sustainability of these systems, but there has been little focus on the management of these canals.

\section{Conclusions}

This study showed that the combination of methods aided the understanding of biogeochemical processes of nutrients in IRSPs. The ponds had highly variable denitrification rates with low denitrification efficiency. Denitrification rates were significantly positively correlated with chlorophyll $a$ concentrations, suggesting carbon limitation. $\mathrm{NO}_{3}{ }^{-}, \mathrm{NH}_{4}{ }^{+}$and $\mathrm{PO}_{4}{ }^{3-}$ concentrations in the water column were high despite low sediment nutrient fluxes. Given the low nutrient fluxes and removal of $\mathrm{N}$ by denitrification, high nutrient loads were likely derived from incoming water. Therefore, these systems are 
514 net nutrient removal mechanisms, rather than contributing to eutrophication in adjacent

515 waterways. Pond management needs to be altered to improve the efficiency of $\mathrm{N}$ removal 516 and improve water quality in IRSPs.

517

\section{Acknowledgements}

519 Luu Duc Dien’s PhD research was supported by a John Allwright Fellowship and Griffith

520 University. The other authors were supported by an Australian Centre for International 521 Agricultural Research (ACIAR) grant (SMCN/2010/083). We would like to thank Le Huu 522 Hiep, Tran Minh Thien, Nguyen Minh Duong, Le Van Truc and Rad Bak for field and 523 laboratory assistance, and the farmers in Thoi Binh District, Ca Mau province, Vietnam for 524 their generously allowing access onto their rice-shrimp ponds.

525 
527

528

529

530

531

532

533

534

535

536

537

538

539

540

541

542

543

544

545

546

547

548

549

550

551

552

553

554

ADB, 2013. Climate Risk in the Mekong Delta: Ca Mau and Kien Giang Provinces of Vietnam. Asian Development Bank (145 pp).

Alam, M.J., Islam, M.L., Saha, S.B., Tuong, T.P., Joffre, O., 2010. Improving the productivity of the rice-shrimp system in the Southwest Coastal Region of Bangladesh. In: Hoanh, C.T., Szuster, B., Kam, S.P., Noble, A., Ismail, A.M. (Eds), Tropical deltas and coastal zones community, environment and food production at the land-water interface. Comprehensive Assessment of Water Management in Agriculture Series. UK: CABI Publishing, pp. 93-105.

Alongi, D.M., 2014. Carbon cycling and storage in mangrove forests. Annu. Rev. Mar. Sci. 6, 195-219. doi:10.1146/annurev-marine-010213-135020

Alongi, D.M., Johnston, D.J., Xuan, T.T., 2000. Carbon and nitrogen budgets in shrimp ponds of extensive mixed shrimp-mangrove forestry farms in the Mekong delta, Vietnam. Aquac. Res. 31, 387-399.

Amatya, I.M., Kansakar, B.R., Tare, V., Fiksdal, L., 2009. Impact of temperature on biological denitrification process. J. Inst. Eng. 7, 121-126.

APHA, 2005. Standard Methods For The Examination Of Water And Wastewater, 21st Ed. American Public Health Association, Washington D.C., USA.

Avnimelech, Y., Ritvo, G., 2003. Shrimp and fish pond soils: processes and management. Aquaculture 220, 549-567.

Be, T.T., Dung, L.C., Brennan, D., 1999. Environmental costs of shrimp culture in the rice growing regions of the Mekong Delta. Aquac. Econ. Manag. 3(1), 31-42.

Berg, P., Risgaard-Petersen, N., Rysgaard, S., 1998. Interpretation of Measured Concentration Profiles in Sediment Pore Water. Limnol. Oceanogr. 43, 1500-1510.

Binh, T.N.K.D., Vromant, N., Hung, N.T., Boon, E.K., Hens, L., 2005. Land Cover Changes between 1968 and 2003 in Cai Nuoc, Ca Mau Peninsula, Vietnam. Environ. Dev. Sustain. 7, 519-536. doi 10.1007/s10668-004-6001-z.

Boyd, C.E., 1995. Bottom soils, sediment and pond aquaculture. New York: Chapman \& Hall. 
Burford, M.A., Rothlisberg, P.C., Revill, A.T., 2009. Sources of nutrients driving production in the Gulf of Carpentaria, Australia - a shallow tropical shelf system. Mar. Freshwater Res. 60, 1044-1053.

Burgin, A.J., Hamilton, S.K., 2007. Have We Overemphasized the Role of Denitrification in Aquatic Ecosystems? A Review of Nitrate Removal Pathways. Front. Ecol. Environ. 5(2), 89-96.

Can, N.D., 2011. Transformation of farming systems in coastal Mekong Delta: Seeking for better management and sustainability. The 6th International symposium on Structural Transformation of Vietnamese Agriculture and Rural Society in the period of Globalization, Industrialization, Modernization, Kagoshima University, Japan. doi:10.13140/2.1.1279.7768

Castine, S.A., Erler, D.V., Trott, L.A., Paul, N.A., de Nys, R., Eyre, B.D., 2012. Denitrification and Anammox in Tropical Aquaculture Settlement Ponds: An Isotope Tracer Approach for Evaluating N2 Production. PLoS ONE 7(9): e42810. doi:10.1371/journal.pone.0042810.

Cook, P.L.M., Revill, A.T., Butler, E.C.V., Eyre, B.D., 2004. Carbon and nitrogen cycling on intertidal mudflats of a temperate Australian estuary. II. Nitrogen cycling. Mar. Ecol. Prog. Ser. 280, 39-54

Dalsgaard, T. (Ed.), Nielsen, L.P., Brotas, V., Viaroli, P., Underwood, G., Nedwell, D.B., Sundbäck, K., Rysgaard, S., Miles, A., Bartoli. M., Dong, L., Thornton, D.C.O., Ottosen, L.D.M., Castaldelli, G., Risgaard-Petersen, N., 2000. Protocol handbook for NICE - Nitrogen cycling in estuaries: A project under the EU research programme: Marine Science and Technology (MAST III). National Environmental Research Institute, Denmark (62 pp).

Dalsgaard, T., Canfield, D.E., Petersen, J., Thamdrup, B., Acuna-Gonzalez, J., 2003. N2 production by the anammox reaction in the anoxic water column of Golfo Dulce, Costa Rica. Nature 422, 606-608.

Davison, W., Zhang, H., Grime, G.W., 1994. Performance characteristics of gel probes used for measuring the chemistry of pore waters. Environ. Sci. Technol. 28, 16231632. 
Díaz, R., Rabalais, N.N., Breitburg, D.L., 2012. Agriculture’s Impact on Aquaculture: Hypoxia and Eutrophication in Marine Waters. Report under Directorate for Trade and Agriculture for the OECD (Organisation for Economic Co-operationand Development) (45 pp).

Dien, L.D., Hiep, L.H., Hao, N.V., Sammut, J., Burford, M.A., 2018. Comparing nutrient budgets in integrated rice-shrimp ponds and shrimp grow-out ponds. Aquaculture, 484, 250-258. doi:10.1016/j.aquaculture.2017.11.037.

Dien, L.D., Hiep, L.H., Stephen, J.F., Chen, C., Sammut, J., Burford, M.A., 2019. Is low shrimp survival in integrated rice-shrimp ponds related to sediment oxygen demand? Aquaculture, 512, 734315. doi:10.1016/j.aquaculture.2019.734315.

Dong, L.F., Nedwell, D.B., Stott, A., 2006. Sources of nitrogen used for denitrification and nitrous oxide formation in sediments of the hypernutrified Colne, the nutrified Humber, and the oligotrophic Conwy estuaries, United Kingdom. Limnol. Oceanogr. 50, 545-557.

Dong, L.F., Smith, C.J., Papaspyrou, S., Stott, A., Osborn, A.M., Nedwell, D.B., 2009. Changes in benthic denitrification, nitrate ammonification, and anammox process rates and nitrate and nitrite reductase gene abundances along an estuarine nutrient gradient (the Colne estuary, United Kingdom). Appl. Environ. Microbiol., 75(10), 3171-3179. doi:10.1128/AEM.02511-08.

Dong, L.F., Sobey, M.N., Smith, C.J., Rusmana, I., Phillips, W., Stott, A., Osborn, A.M., Nedwell, D.B., 2011. Dissimilatory reduction of nitrate to ammonium, not denitrification or anammox, dominates benthic nitrate reduction in tropical estuaries. Limnol. Oceanogr., 56(1), 279-291. doi:10.4319/lo.2011.56.1.0279

Gardner, W.S., McCarthy, M.J., 2009. Nitrogen dynamics at the sediment-water interface in shallow, sub-tropical Florida Bay: Why denitrification efficiency may decrease with increased eutrophication. Biogeochemistry 95, 185-198. doi:10.1007/s10533009-9329-5.

Giblin, A., Tobias, C., Song, B., Weston, N., Banta, G., Rivera-Monroy, V., 2013. The Importance of Dissimilatory Nitrate Reduction to Ammonium (DNRA) in the Nitrogen Cycle of Coastal Ecosystems. Oceanography 26(3), 124-131. doi:10.5670/oceanog.2013.54 
Giblin, A.E., Weston, N., Banta, G., Tucker, J., Hopkinson, C.S., 2010. The effects of salinity on nitrogen loss from an oligohaline estuarine sediment. Estuaries Coast. 33(1), 1054-1068. doi:10.1007/s12237-010-9280-7.

Jantti, H., Stange, F., Leskinen, E., Hietanen, S., 2011. Seasonal variation in nitrification and nitrate-reduction pathways in coastal sediments in the Gulf of Finland, Baltic Sea. Aquat. Microb. Ecol. 63, 171-181.

Jensen, M.M., Thamdrup, B., Dalsgaard, T., 2007. Effects of specific inhibitors on anammox and denitrification in marine sediments. Appl. Environ. Microbiol. 73(10), 3151-3158.

Kaiser, D., Kowalski, N., Böttcher, M.E., Yan, B., Unger, D., 2015. Benthic Nutrient Fluxes from Mangrove Sediments of an Anthropogenically Impacted Estuary in Southern China. J. Mar. Sci. Eng. 3, 466-491. doi:10.3390/jmse3020466.

Kartal, B., Kuypers, M.M., Lavik, G., Schalk, J., Op den Camp, H.J.M., Jetten, M.S.M., Strous, M., 2007. Anammox bacteria disguised as denitrifiers: nitrate reduction to dinitrogen gas via nitrite and ammonium. Environ. Microbiol. 9, 635-642. doi: 10.1111/j.1462-2920.2006.01183.x

Khiem, N.T., Khai, T.T., 2008. Technology change in rice production and rice farmer income in Vietnam Mekong Delta lowland. Proceeding of the Forum on "Rice Policy Research: Key Issues from National Perspectives” Workshop. International Rice Research Institute, Los Banos, the Philippines.

Koch, M.S., Maltby, E., Oliver, G.A., Baker, A., 1992. Factors controlling denitrification rates of tidal mudflats and fringing salt marshes in South-west England. Estuar. Coast. Shelf Sci. 34, 471-485.

Kraft, B., Tegetmeyer, H.E., Sharma, R., Klotz, M.G., Ferdelman, T.G., Hettich, R.L., Geelhoed, J.S., Strous, M., 2014. The environmental controls that govern the end product of bacterial nitrate respiration. Science 345, 676-679. doi: 10.1126/science.1254070.

Krom, M., Davison, P., Zhang, H., Davison, W., 1994. High-resolution pore-water sampling with a gel sampler. Limnol. Oceanogr. 39, 1967-1972. 
Kuwae, T., Kibe, E., Nakamura, Y., 2003. Effect of emersion and immersion on the porewater nutrient dynamics of an intertidal sandflat in Tokyo Bay. Estuar. Coast. Shelf Sci. 57, 929-940.

Leigh, C., Hiep, L.H., Stewart-Koster, B., Vien, D.M., Condon, J., Sang. N.V., Sammut, J., Burford, M.A., 2017. Concurrent rice-shrimp-crab farming systems in the Mekong Delta: Are conditions (sub)optimal for crop production and survival? Aquac. Res. 00, 1-12. doi: 10.1111/are.13338.

Mortimer, R.J.G., Krom, M.D., Watson, P.G., Frickers, P.E., Davey, J.T., Clifton, R.J., 1998. Sediment-water exchange of nutrients in the intertidal zone of the Humber estuary, UK. Mar. Pollut. Bull. 37, 261-279.

Nhan, D.K., Trung, N.H., Sanh, N.V, 2011. The impact of weather variability on rice and aquaculture production in the Mekong Delta. In: Stewart, M.A., Coclanis, P.A. (Eds.), Environmental change and agricultural sustainability in the Mekong Delta. Dordrecht, The Netherlands: Springer, pp. 437-451.

Paez-Osuna, F., Guerrero-Galvan, S.R., Ruiz-Fernandez, A.C., Espinoza-Angulo, R., 1997. Fluxes and mass balances of nutrients in a semi-intensive shrimp farm in Northwestern Mexico. Mar. Pollut. Bull. 34(5), 290-297.

Preston, N., Brennan, D., Clayton, H., 2003. An overview of the project research. In: Preston, N., Clayton, H. (Eds), Rice-shrimp farming in the Mekong Delta: biophysical and socioeconomic issues. ACIAR Technical Reports No. 52e, pp. 714.

Reay, W.G., Gallagher, D.L., Simmons, G.M. 1995. Sediment-water column oxygen and nutrient fluxes in nearshore environments of the lower Delmarva Peninsula, USA. Mar. Ecol. Prog. Ser. 118, 215-227.

Rivera-Monroy, V.H., Twilley, R.R., Boustany, R.G., Day, W.J., Vera-Herrera, F., Ramirez, M., 1995. Direct denitrification in mangrove sediments in Terminos Lagoon, Mexico. Mar. Ecol. Prog. Ser. 126(1-3), 97-109.

Song, G.D., Liu, S.M., Marchant, H., Kuypers, M.M., Lavik, G., 2013. Anammox, denitrification and dissimilatory nitrate reduction to ammonium in the East China Sea sediment. Biogeosciences 10(11), 6851-6864. doi:10.5194/bg-10-6851-2013 
Statham, P.J., 2012. Nutrients in estuaries - An overview and the potential impacts of climate change. Sci. Total Environ. 434, 213-227. doi:10.1016/j.scitotenv.2011.09.088

Tho, N., Merckx, R., Ut, V.N., 2013. Impacts of saline water irrigation and shrimp pond discharges on the surrounding waters of a coastal district in the Mekong Delta of Vietnam. Environ. Earth Sci. 71(5), 2015-2027. doi:10.1007/s12665-013-2603-9.

Tho, N., Vromant, N., Hung, N. T., Hens, L., 2006. Organic Pollution and Salt Intrusion in Cai Nuoc District, Ca Mau Province, Vietnam. Water Environ. Res. 78(7), 716723. doi:10.2175/106143006x101755.

Tiedje, J.M., 1988. Ecology of denitrification and dissimilatory nitrate reduction to ammonium. In: Zehnder, A. (Eds), Biology of Anaerobic Microorganisms. John Wiley \& Sons, New York, pp. 179-243.

Tuan, P.A., Hai, T.N., Tu, T.Q., 2016. Development of rice-shrimp farming in Mekong River Delta, Vietnam. United States Agency for International Development Mekong Adaptation and Resilience to Climate Change (USAID Mekong ARCC), Can Tho University, Vietnam.

Urban, N.R., Dinkel, C., Wehrli, B., 1997. Solute transfer across the sediment surface of a eutrophic lake: I. Porewater profiles from dialysis samplers. Aquat. Sci. 59, 1-25.

Velinsky, D.J., Paudel, B., Quirk, T., Piehler, M., Smyth, A., 2017. Salt Marsh Denitrification Provides a Significant Nitrogen Sink in Barnegat Bay, New Jersey. J. Coast. Res. 78, 70-78.

Wahab, M.A., 2003. Environmental impacts of shrimp farming in the coastal areas of Bangladesh. In: Wahab, M.A. (Eds), Environmental and socioeconomic impacts of shrimp farming in Bangladesh. Dhaka: BRAC Centre, Dhaka, Bangladesh, pp. 1932.

Wang, Y.X., Li, X.Y., Lee, J.H., 2008. Influence of the biomass content in sediment on the sediment nutrient flux for a pulsed organic load. Mar. Pollut. Bull. 57(6-12), 681688. doi:10.1016/j.marpolbul.2007.12.016.

Wiyoto, W., Sukenda, S., Harris, E., Nirmala, K., Djokosetiyanto, D., Ekasari, J., 2017. The effects of sediment redox potential and stocking density on Pacific white 

shrimp Litopenaeus vannamei production performance and white spot syndrome virus resistance. Aquac. Res. 48, 2741-2751. doi:10.1111/are.13107.

Zhang, H., Davison, W., 1999. Diffusional characteristics of hydrogels used in DGT and DET techniques. Anal. Chim. Acta. 398, 329-340.

Zhong, D., Wang, F., Dong, S., Li, L., 2015. Impact of Litopenaeus vannamei bioturbation on nitrogen dynamics and benthic fluxes at the sediment-water interface in pond aquaculture. Aquac. Int. 23(4), 967-980. doi:10.1007/s10499-014-9855-6. 


\section{Tables}

Table 1. Physico-chemical parameters in the water column (mean \pm SD) comparing wet and dry seasons for 2016 and 2017, $\mathrm{n}=24$. DO = dissolved oxygen. AFDW = ash free dry weight. DON = dissolved organic nitrogen. DOP = dissolved organic phosphorus.

\begin{tabular}{|c|c|c|c|c|}
\hline Parameters & Dry & Wet & 2016 & 2017 \\
\hline Temperature $\left({ }^{\circ} \mathrm{C}\right)$ & $34.2 \pm 3.4$ & $30.5 \pm 1.6$ & $33.0 \pm 4.4$ & $31.8 \pm 1.6$ \\
\hline $\mathrm{DO}\left(\mathrm{mg} \mathrm{L}^{-1}\right)$ & $6.38 \pm 2.14$ & $5.08 \pm 1.65$ & $6.02 \pm 2.20$ & $5.44 \pm 1.84$ \\
\hline $\mathrm{pH}$ & $7.92 \pm 0.52$ & $8.11 \pm 0.56$ & $7.74 \pm 0.61$ & $8.29 \pm 0.21$ \\
\hline Salinity (ppt) & $29.3 \pm 14.9$ & $2.9 \pm 0.8$ & $22.4 \pm 21.8$ & $8.9 \pm 8.6$ \\
\hline Euphotic depth (m) & $1.4 \pm 0.2$ & $0.7 \pm 0.1$ & $1.0 \pm 0.6$ & $0.9 \pm 0.3$ \\
\hline TSS $\left(\mathrm{mg} \mathrm{L}^{-1}\right)$ & $80.6 \pm 7.5$ & $94.5 \pm 30.1$ & $76.0 \pm 10.6$ & $99.1 \pm 25.0$ \\
\hline AFDW $\left(\mathrm{mg} \mathrm{L}^{-1}\right)$ & $27.7 \pm 9.6$ & $46.0 \pm 4.5$ & $33.8 \pm 13.8$ & $39.9 \pm 11.0$ \\
\hline $\mathrm{NH}_{4}-\mathrm{N}\left(\mathrm{mg} \mathrm{L}^{-1}\right)$ & $0.148 \pm 0.056$ & $0.287 \pm 0.214$ & $0.225 \pm 0.203$ & $0.210 \pm 0.142$ \\
\hline $\mathrm{NO}_{3}-\mathrm{N}\left(\mathrm{mg} \mathrm{L}^{-1}\right)$ & $0.232 \pm 0.228$ & $0.067 \pm 0.034$ & $0.239 \pm 0.224$ & $0.050 \pm 0.010$ \\
\hline $\mathrm{NO}_{2}-\mathrm{N}\left(\mathrm{mg} \mathrm{L}^{-1}\right)$ & $0.011 \pm 0.008$ & $0.039 \pm 0.023$ & $0.026 \pm 0.023$ & $0.027 \pm 0.021$ \\
\hline $\mathrm{DON}\left(\mathrm{mg} \mathrm{L}^{-1}\right)$ & $0.215 \pm 0.126$ & $0.382 \pm 0.263$ & $0.349 \pm 0.315$ & $0.248 \pm 0.170$ \\
\hline $\mathrm{TN}\left(\mathrm{mg} \mathrm{L}^{-1}\right)$ & $0.828 \pm 0.196$ & $1.059 \pm 0.189$ & $0.921 \pm 0.087$ & $0.966 \pm 0.318$ \\
\hline $\mathrm{PO}_{4}-\mathrm{P}\left(\mathrm{mg} \mathrm{L}^{-1}\right)$ & $0.115 \pm 0.052$ & $0.113 \pm 0.034$ & $0.134 \pm 0.042$ & $0.098 \pm 0.028$ \\
\hline $\mathrm{DOP}\left(\mathrm{mg} \mathrm{L}^{-1}\right)$ & $0.114 \pm 0.084$ & $0.133 \pm 0.053$ & $0.143 \pm 0.061$ & $0.104 \pm 0.055$ \\
\hline Total P (mg L $\left.{ }^{-1}\right)$ & $0.255 \pm 0.132$ & $0.272 \pm 0.109$ & $0.298 \pm 0.132$ & $0.241 \pm 0.115$ \\
\hline Chlorophyll $a\left(\mu \mathrm{g} \mathrm{L}^{-1}\right)$ & $12.3 \pm 5.5$ & $55.8 \pm 34.8$ & $45.2 \pm 27.0$ & $19.9 \pm 6.9$ \\
\hline Sulfide (mg L ${ }^{-1}$ ) & $0.002 \pm 0.001$ & $0.005 \pm 0.001$ & $0.003 \pm 0.001$ & $0.004 \pm 0.002$ \\
\hline TOC $\left(\mathrm{mg} \mathrm{L}^{-1}\right)$ & $15.1 \pm 1.2$ & $13.3 \pm 1.5$ & $15.0 \pm 1.6$ & $13.4 \pm 1.3$ \\
\hline
\end{tabular}


719 Table 2. Background physico-chemical parameters in the sediment (mean \pm SD)

720 comparing ditch and platform, and dry and wet seasons. Sampling was only conducted in

721 the first year (2016), $\mathrm{n}=12$.

\begin{tabular}{lllll}
\hline Parameters & Ditch & Platform & Dry & Wet \\
\hline TOC (\%) & $3.16 \pm 1.39$ & $4.54 \pm 2.31$ & $5.27 \pm 1.68$ & $2.43 \pm 0.58$ \\
Total N (\%) & $0.28 \pm 0.12$ & $0.30 \pm 0.11$ & $0.38 \pm 0.04$ & $0.19 \pm 0.03$ \\
Total P (\%) & $0.03 \pm 0.00$ & $0.04 \pm 0.00$ & $0.04 \pm 0.00$ & $0.03 \pm 0.01$ \\
Chlorophyll $a\left(\mathrm{mg} \mathrm{m}^{-2}\right)$ & $0.85 \pm 0.93$ & $2.17 \pm 2.43$ & $2.95 \pm 1.54$ & $0.16 \pm 0.09$ \\
\hline
\end{tabular}

722

723 
724 Table 3. Annual $\mathrm{N}$ removal (\%) via denitrification across the two IRSPs (mean \pm SD), $\mathrm{n}=$ $725 \quad 24$

\begin{tabular}{llll}
\hline Year & $\begin{array}{l}\text { N removal by denitrification } \\
\left(\mathrm{kg} \mathrm{y}^{-1}\right)\end{array}$ & $\begin{array}{l}\text { Total N in the pond } \\
(\mathrm{kg} / \text { year })\end{array}$ & $\begin{array}{l}\text { Annual efficiency } \\
(\%)\end{array}$ \\
\hline 2016 & $0.22 \pm 0.09$ & $12.52 \pm 1.78$ & $1.76 \pm 0.62$ \\
2017 & $0.19 \pm 0.07$ & $11.46 \pm 1.45$ & $1.66 \pm 0.59$ \\
Mean & $0.21 \pm 0.08$ & $11.99 \pm 1.64$ & $1.71 \pm 0.61$ \\
\hline
\end{tabular}

726

727 
728 Table 4. The Pearson correlation between denitrification rates and parameters in the

729 sediment, $\mathrm{n}=24$

\begin{tabular}{lcccc}
\hline & Chlorophyll $a^{*}$ & TN & TP & TOC \\
\hline Pearson correlation & 0.894 & 0.640 & 0.821 & 0.371 \\
Significance (1-tailed) & 0.049 & 0.180 & 0.090 & 0.315 \\
\hline
\end{tabular}

730

731 
Table 5. Mean ( $\pm \mathrm{SD}$ ) flux rates of $\mathrm{NH}_{4}{ }^{+}, \mathrm{NO}_{2}{ }^{-}, \mathrm{NO}_{3}{ }^{-}, \mathrm{PO}_{4}{ }^{3-}, \mathrm{S}^{2-}\left(\mathrm{mmol} \mathrm{m}{ }^{-2} \mathrm{~d}^{-1}\right)$ of the combined two IRSPs. Positive values indicate flux out of 733 the sediment; negative values indicate flux into the sediment.

\begin{tabular}{|c|c|c|c|c|c|}
\hline Season & $\begin{array}{c}\mathbf{N H}_{4}^{+} \\
\left(\mathrm{mmol} \mathrm{m}{ }^{-2} \mathrm{~d}^{-1}\right)\end{array}$ & $\begin{array}{c}\mathbf{N O}^{-} \\
\left(\mathrm{mmol} \mathrm{m}{ }^{-2} \mathrm{~d}^{-1}\right)\end{array}$ & $\begin{array}{c}\mathbf{N O}_{3}^{-} \\
\left(\mathrm{mmol} \mathrm{m}^{-2} \mathrm{~d}^{-1}\right)\end{array}$ & $\begin{array}{c}\mathbf{P O}_{4}{ }^{3-} \\
\left(\mathrm{mmol} \mathrm{m}^{-2} \mathrm{~d}^{-1}\right)\end{array}$ & $\begin{array}{c}\mathbf{S}^{2-} \\
\left(\mathrm{mmol} \mathrm{m} \mathrm{m}^{-2} \mathrm{~d}^{-1}\right)\end{array}$ \\
\hline Dry 2016 & $0.26 \pm 0.07$ & $-0.05 \pm 0.04$ & $-0.32 \pm 0.11$ & $-0.15 \pm 0.07$ & $-0.03 \pm 0.01$ \\
\hline Wet 2016 & $-0.57 \pm 0.05$ & $-0.08 \pm 0.04$ & $-0.17 \pm 0.08$ & $-0.09 \pm 0.08$ & $-0.02 \pm 0.01$ \\
\hline Dry 2017 & $-0.44 \pm 0.09$ & $-0.04 \pm 0.02$ & $-0.21 \pm 0.15$ & $0.10 \pm 0.06$ & $-0.03 \pm 0.01$ \\
\hline Wet 2017 & $-0.37 \pm 0.08$ & $-0.06 \pm 0.03$ & $-0.16 \pm 0.07$ & $0.09 \pm 0.05$ & $0.01 \pm 0.01$ \\
\hline
\end{tabular}


736 Table 6. Mean flux rates of $\mathrm{NH}_{4}{ }^{+}, \mathrm{NO}_{2}{ }^{-}, \mathrm{NO}_{3}{ }^{-}, \mathrm{PO}_{4}{ }^{3-}, \mathrm{S}^{2-}\left(\mathrm{mmol} \mathrm{m}^{-2} \mathrm{~d}^{-1}\right)$ of the combined two IRSPs in 2017 based on the diffusive equilibrium 737 in thin films method. SWI = sediment-water interface. The linear regression coefficients $\left(r^{2}\right)>0.95$, showing the high certainty.

\begin{tabular}{|c|c|c|c|c|c|c|}
\hline Season & Flux & $\begin{array}{c}\mathbf{N H}_{4}^{+} \\
\left(\mathrm{mmol} \mathrm{m}^{-2} \mathrm{~d}^{-1}\right)\end{array}$ & $\begin{array}{c}\mathbf{N O}_{2}^{-} \\
\left(\mathrm{mmol} \mathrm{m}^{-2} \mathrm{~d}^{-1}\right)\end{array}$ & $\begin{array}{c}\mathbf{N O}_{3}^{-} \\
\left(\mathrm{mmol} \mathrm{m}^{-2} \mathrm{~d}^{-1}\right)\end{array}$ & $\begin{array}{c}\mathbf{P O}_{4}{ }^{3-} \\
\left(\mathrm{mmol} \mathrm{m}^{-2} \mathrm{~d}^{-1}\right)\end{array}$ & $\begin{array}{c}\mathbf{S}^{2-} \\
\left(\mathrm{mmol} \mathrm{m}{ }^{-2} \mathrm{~d}^{-1}\right)\end{array}$ \\
\hline \multirow{2}{*}{ Dry 2017} & from the water surface to SWI & 0.34 & 0.03 & 0.26 & -0.08 & 0.02 \\
\hline & from SWI to sediment & -0.27 & -0.01 & -0.14 & 0.08 & -0.01 \\
\hline \multirow{2}{*}{ Wet 2017} & from the water surface to SWI & 0.24 & 0.03 & -0.33 & -0.03 & 0.01 \\
\hline & from SWI to sediment & -0.12 & -0.02 & -0.03 & 0.03 & 0.01 \\
\hline
\end{tabular}




\section{Figure captions}

Figure 1. Study site layout showing two integrated rice-shrimp ponds (symbolled TB1 and TB2) in Tan Bang Ward, Thoi Binh District, Ca Mau province, Vietnam. The total area of TB1 is 1.5 ha, and that is 2.0 ha of TB2.

Figure 2. Mean ( \pm SD) monthly water temperature $\left({ }^{\circ} \mathrm{C}\right)$ and salinity (ppt) across two integrated rice-shrimp ponds in 2016 and 2017. The arrows showed time of experiments conducted: in the dry season (April 2016, April 2017) and the wet season (October 2016, October 2017).

Figure 3. Mean $( \pm \mathrm{SD})$ denitrification rates $\left(\mu \mathrm{mol} \mathrm{N} \mathrm{m} \mathrm{h}^{-2}\right.$ ) between the dry and wet seasons, between the ditch and platform, and between the light (i.e. day) and dark (i.e. night) of two IRSPs over the two-year period (2016-2017). Different letters indicate significant differences between seasons $(p<0.05)$.

Figure 4. Mean ( \pm SD) DNRA rates (nmol m $\left.\mathrm{m}^{2} \mathrm{~h}^{-1}\right)$ comparing dry and wet seasons, and ditch and platform of two IRSPs in 2017. Different letters indicate significant differences between seasons $(p<0.05)$.

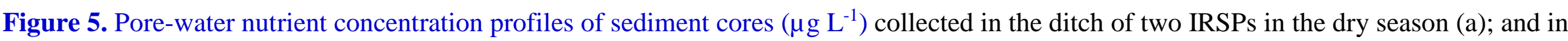
the wet season (b). $1 \rightarrow 5 \mathrm{~cm}$ : above the sediment (i.e, water layer); $-1 \rightarrow-10 \mathrm{~cm}$ : under the sediment. The thicker line at $0 \mathrm{~cm}$ sediment depth indicates where the sediment starts. Significantly different concentrations in surface sediments between samplings are marked by different symbols in the top corner of panels $(p<0.05)$. 
FIGURES

755

Figure 1.

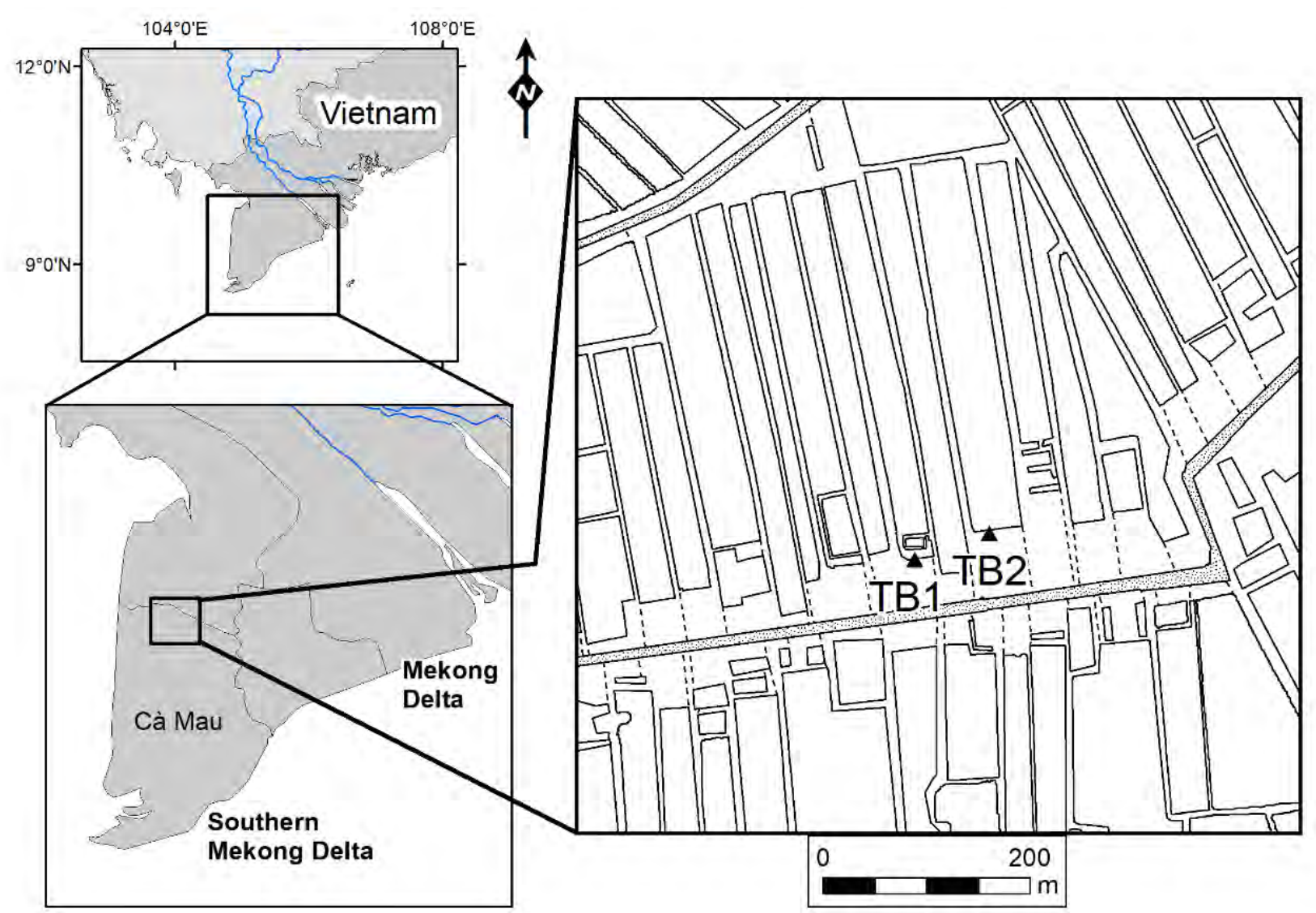


Figure 2.
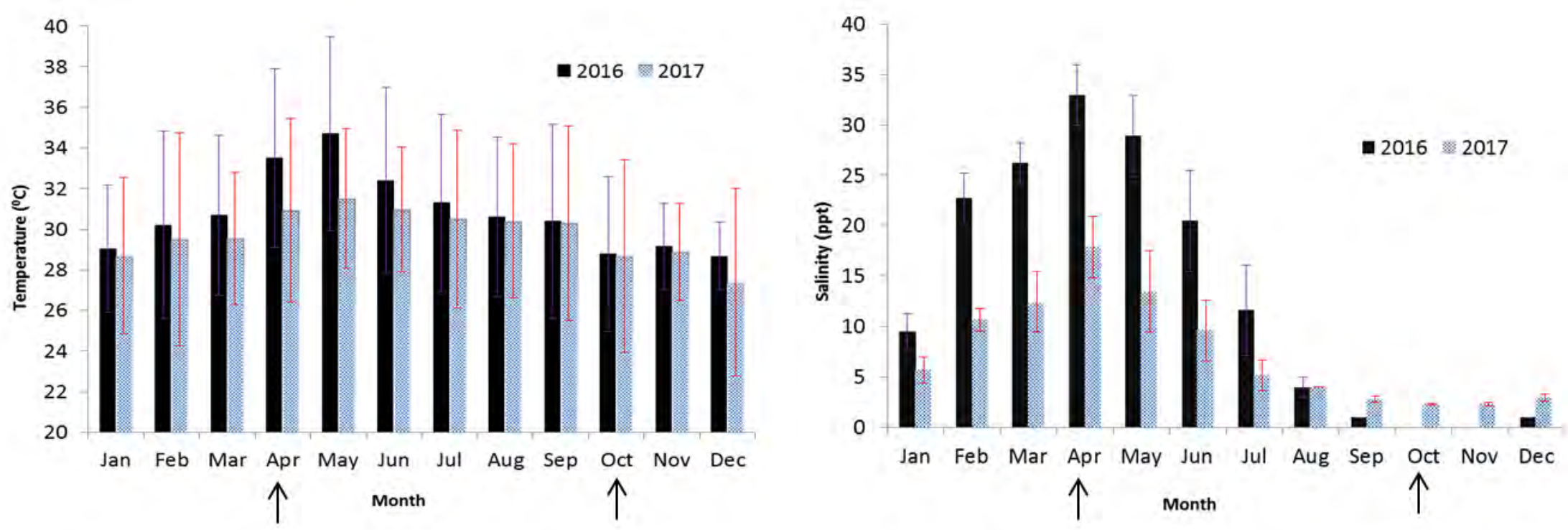
$761 \quad$ Figure 3.

762
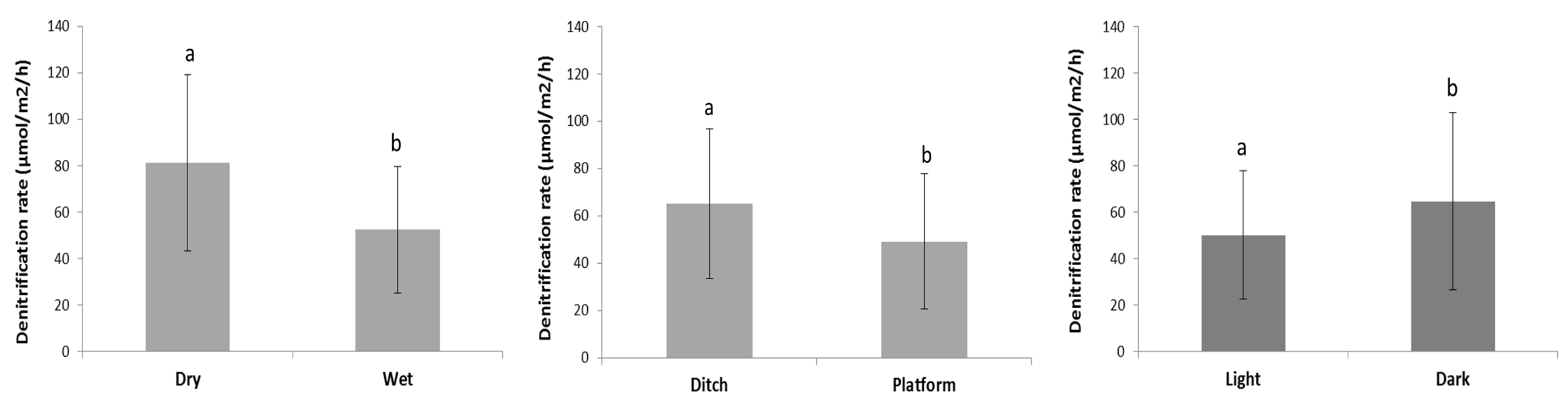

763 
Figure 4.

765
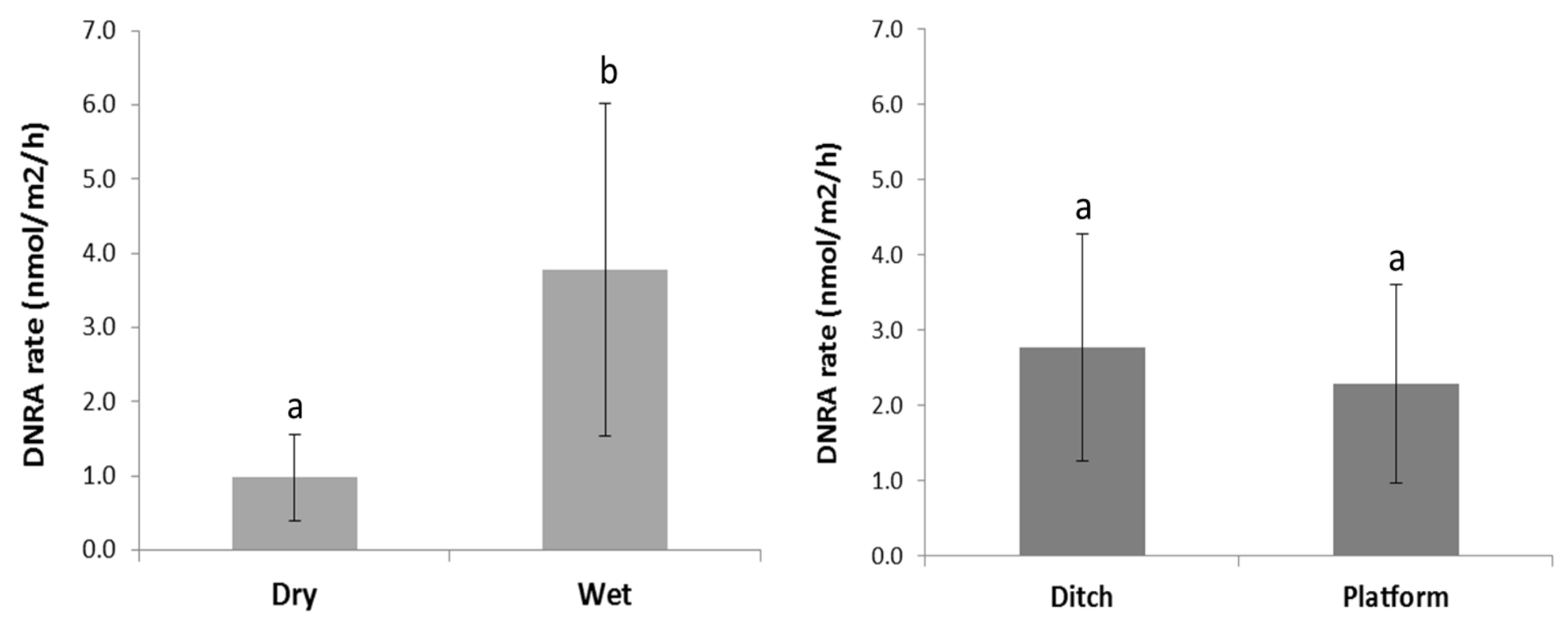
$767 \quad$ Figure 5.

768 (a) The dry season
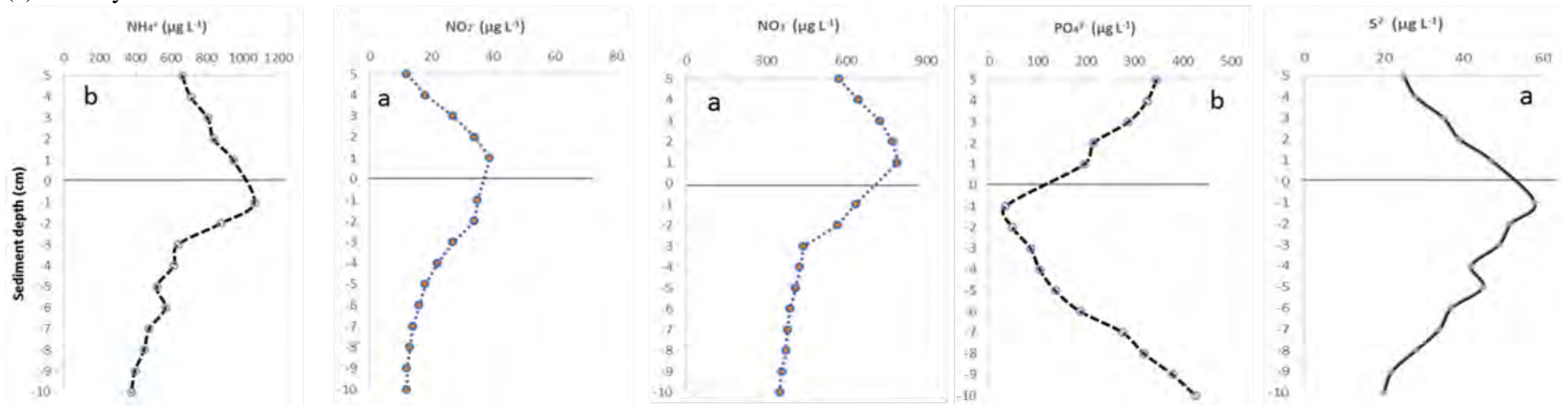

770 (b) The wet season

$\mathrm{NHA}^{2}\left(\mu \mathrm{g} \mathrm{L}^{4}\right)$

NO: $\left(\mu \mathrm{L}^{-1}\right)$

NO, ( $\left.\mu \mathrm{g} \mathrm{L}^{-1}\right)$

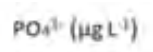
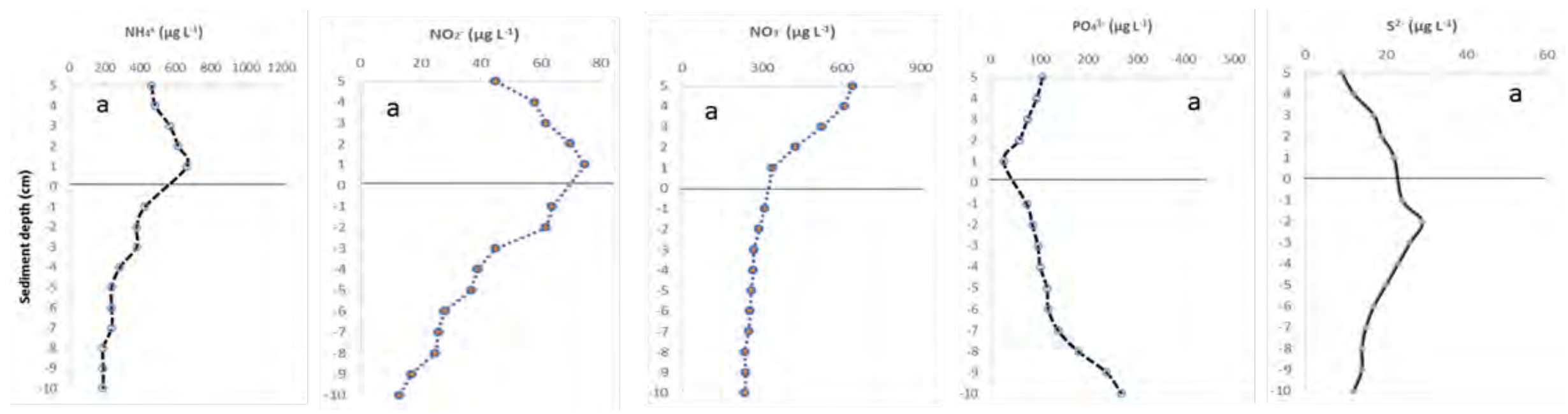